(2) Open Access Full Text Article

\title{
Personalized contraceptive counseling: helping women make the right choice
}

\author{
This article was published in the following Dove Press journal: \\ Open Access Journal of Contraception \\ II May 2016 \\ Number of times this article has been viewed
}

\section{Janelle Rodriguez \\ Mona Abutouk \\ Karen Roque \\ Aparna Sridhar}

Department of Obstetrics and Gynecology, David Geffen School of Medicine at University of California Los Angeles, Los Angeles, CA, USA
Correspondence: Aparna Sridhar Department of Obstetrics and Gynecology, David Geffen School of Medicine at University of California Los Angeles, 10833 Le Conte Ave, Los Angeles, CA 90095, USA

Email asridhar@mednet.ucla.edu
Abstract: Unintended pregnancy is a significant problem with medical, social, and economic consequences. Half of unintended pregnancies are a result of no contraceptive use; while the other half results from contraceptive inconsistencies, or method failure. Women have an array of contraceptive options to choose from, each of which differs significantly in terms of usage, efficacy, side effects, risks, and noncontraceptive benefits. Determining the best tool for communication is a challenge. In addition, the choice of contraceptive method differs among women with medical problems. Not all contraceptive methods are suitable for women with certain medical problems. In this review, we discuss different methods of counseling and the tools available for sharing contraception information.

Keywords: birth control, decision aid, contraceptive

\section{Introduction}

Unintended pregnancy is still a critical public health problem in the USA. There are significant costs - economical, medical, and social ${ }^{1}$ - associated with unintended pregnancies as well as suboptimal maternal and child health following birth. ${ }^{1-5}$ As of $2008,51 \%$ of pregnancies in the USA were unintended. ${ }^{6}$ A proposed solution to reduce the rates of unintended pregnancies by half is through the use of highly effective contraceptives. ${ }^{1,7}$ In fact, half of the unintended pregnancies are a result of no contraceptive use, while the other half results from contraceptive inconsistencies or method failure. ${ }^{8}$ Underuse of effective contraception is another factor which contributes to high rates of unintended pregnancy in the USA. ${ }^{9,10}$ Women have an array of contraceptive options to choose from, each of which differs significantly in terms of usage, efficacy, side effects, risks, and noncontraceptive benefits. How should we best inform women about the contraceptive methods available to reduce the rates of unintended pregnancies? Health communication is regarded as an important marker of quality of care by the Institute of Medicine ${ }^{11}$ and is associated with improvement in patient outcomes. ${ }^{12,13}$ However, determining the best tool for communication is a challenge, as many factors must be considered, including a woman's reproductive life plans, health literacy level, and socioeconomic situation. ${ }^{14,15}$ These factors are critical as there are many causes of unintended pregnancies including, but not limited to, poor access to family planning services, inconsistent or incorrect use of contraceptive methods, and discontinuation of contraceptives due to associated side effects. ${ }^{16,17}$ Many contraception counseling options are available and have been scientifically studied. It is important to note that no literature reports till date have proved the benefit of contraception counseling or decision aids 
in the setting of reducing unintended pregnancies. ${ }^{18,19}$ Most studies focus on short-term measurable outcomes such as contraception choice or knowledge, which indirectly influences unintended pregnancy rates by affecting the correct use of contraceptive methods. This review focuses on a brief overview of the available contraceptive methods and some practices of contraceptive counseling that can be used to help women make the right choice of birth control method.

\section{Contraceptive methods available in the USA}

There is a wide range of contraceptive methods available in the USA, including both permanent and reversible (longacting and short-acting) contraceptives. Permanent and long-acting reversible contraceptives (LARCs) offer the highest effectiveness rates of all methods and are some of the most cost-effective methods of contraception (Table 1).

\section{Role of personal health in contraceptive counseling}

Not all contraceptive methods are suitable for women with certain medical problems.

The Centers for Disease Control and Prevention has released two evidence-based clinical guideline documents regarding contraceptive use for adolescents and adults. The first guideline, US Medical Eligibility Criteria (USMEC) for Contraceptive Use, $2010,{ }^{20}$ helps clinicians not only recognize when a contraceptive method may not be safe to use for a woman, particularly an adolescent, but also when not to withhold a contraceptive method that is safe to use. The second document, US Selected Practice Recommendations (US SPR) for Contraceptive Use, 2013, ${ }^{21}$ provides guidance on how to use contraceptive methods safely and effectively once they are deemed safe for a particular woman. Health care providers are encouraged to use these documents to provide safe and effective contraceptive care to patients seeking family planning services, including adolescents. USMEC and the US SPR were adapted from similar documents by the World Health Organization (WHO), which has been publishing global evidence-based contraceptive guidance since 1996. Recommendations are provided using a numeric scheme of $1-4$, in which category 1 represents a method that is safe to use without restriction and category 4 represents an unacceptable health risk (Table 2).

Most women can safely use all the hormonal contraceptive methods; rarely, women will have a medical condition making the use of a hormonal method inappropriate. USMEC can not only assist with restricting the method use when there is an evidence of risk, but also with facilitating the use where there is an evidence of safety. The most common contraindications for combined hormonal methods are women with high risk of venous thrombosis, migraines with aura, positive antiphospholipid antibodies, and being less than 21 days after giving birth. However, based on the USMEC guidelines, there are very few absolute contraindications to the longer acting methods such as intrauterine devices and implants. Thus, we recommend providers to refer to these documents before conducting a personalized contraception counseling session.

\section{Personalized contraception counseling}

Basic concepts of contraception counseling Given the sensitive and personal nature of discussions, contraception counseling can be challenging for both providers and patients. A recent review by Dehlendorf et $\mathrm{al}^{22}$ delineated best practices for effective and quality contraception counseling. In this review, the authors highlight the best practices for contraception counseling, including developing close personal relationships, building trust, optimizing decision making, and keeping patient's autonomy. In addition, they suggested that adequate counseling regarding the side effects, risks, and efficacy should take priority in any contraception counseling discussion. Other recommendations from these authors included counseling about sexually transmitted infection risk reduction, screening for reproductive coercion, and addressing future fertility concerns with patients at the time of contraception counseling.

There have been many studies that have identified contraception counseling strategies and studied its effect on contraception choice and continuation. In general, a patient-centered approach to counseling is the most popular one. Structured counseling is a frequently discussed method in the literature because it provides a clinical algorithm that is standardized for patient use. This method engages the patient by covering an extensive list of contraceptives, but, in addition, also covers the effectiveness and side effects of each modality. ${ }^{16,23}$ Both audio and visual references are made available during these encounters such that a multisensory approach to learning is also integrated. Patients are also encouraged to ask questions and sometimes supplied with notecards to write down any questions they may have for their physicians. ${ }^{16,23}$ This framework then allows a patient to progress toward an informed choice on a contraceptive method that is both effective and suited to meet her lifestyle preferences. ${ }^{16}$ In the upcoming section of this review, we will highlight some studies that focused on different aspects of contraception counseling. 
Table I Effectiveness of contraceptive methods

\begin{tabular}{|c|c|c|c|c|c|}
\hline Method & $\begin{array}{l}\text { Perfect } \\
\text { use efficacy } \\
(\%)^{* *}\end{array}$ & $\begin{array}{l}\text { Typical } \\
\text { use efficacy } \\
(\%)^{* * *}\end{array}$ & $\begin{array}{l}\text { I-year } \\
\text { continuation } \\
\text { rate }(\%)\end{array}$ & Benefits & Disadvantages \\
\hline \multicolumn{6}{|c|}{ Long-term methods } \\
\hline $\begin{array}{l}\text { Male } \\
\text { sterilization }\end{array}$ & $>99$ & $>99$ & 100 & $\begin{array}{l}\text { Permanent; superior effectiveness; } \\
\text { quick recovery; no partner reliance; } \\
\text { does not interrupt sex }\end{array}$ & $\begin{array}{l}\text { Requires time for procedure; expertise } \\
\text { of provider; risk of infection or surgical } \\
\text { complications; potential of regret; does } \\
\text { not protect against STls }\end{array}$ \\
\hline $\begin{array}{l}\text { Female } \\
\text { sterilization }\end{array}$ & $>99$ & $>99$ & 100 & $\begin{array}{l}\text { Permanent; superior effectiveness; } \\
\text { quick recovery; no partner reliance; } \\
\text { does not interrupt sex; safe while } \\
\text { breastfeeding }\end{array}$ & $\begin{array}{l}\text { Requires time for procedure; expertise } \\
\text { of provider; risk of infection or surgical } \\
\text { complications; potential of regret; does } \\
\text { not protect against STIs }\end{array}$ \\
\hline $\begin{array}{l}\text { Hormonal } \\
\text { implant }\end{array}$ & $>99$ & $>99$ & $83-92$ & $\begin{array}{l}\text { Lasts for up to } 3 \text { years; easily reversible; } \\
\text { easy to use (do not have to do } \\
\text { anything); discreet; can be used while } \\
\text { breastfeeding; does not interrupt sex }\end{array}$ & $\begin{array}{l}\text { Provider needs to place and remove it; } \\
\text { may cause changes in menstrual flow, } \\
\text { headaches, or acne; increased risk of } \\
\text { ectopic pregnancy; does not protect } \\
\text { against STls }\end{array}$ \\
\hline IUDs & $>99$ & $>99$ & $74-88$ & $\begin{array}{l}\text { Can last from } 3 \text { to } 12 \text { years depending } \\
\text { on the IUD chosen; easy to use; } \\
\text { hormonal IUD may make periods } \\
\text { lighter and shorter; copper IUD has no } \\
\text { hormones; discreet; can be used while } \\
\text { breastfeeding; does not interrupt sex }\end{array}$ & $\begin{array}{l}\text { Provider needs to place and remove } \\
\text { it; may cause changes in menstrual } \\
\text { flow; IUD may come out on its own; } \\
\text { increased risk of ectopic pregnancy; } \\
\text { does not protect against STls }\end{array}$ \\
\hline \multicolumn{6}{|c|}{ Short-term methods } \\
\hline $\begin{array}{l}\text { Contraceptive } \\
\text { injection }\end{array}$ & $>99$ & 94 & $23-57$ & $\begin{array}{l}\text { Easy to use; lasts for } 3 \text { months; } \\
\text { discreet; may make periods lighter/ } \\
\text { shorter or cause amenorrhea; may be } \\
\text { used while breastfeeding }\end{array}$ & $\begin{array}{l}\text { Provider needs to give it every } \\
3 \text { months; may cause irregular bleeding, } \\
\text { change in appetite, weight gain }\end{array}$ \\
\hline Vaginal ring & $>99$ & 91 & 54 & $\begin{array}{l}\text { Monthly method (instead of daily/ } \\
\text { weekly); discreet; may make periods } \\
\text { lighter/shorter and regular; may clear } \\
\text { up acne; may reduce menstrual cramps }\end{array}$ & $\begin{array}{l}\text { Need to change it every month; its } \\
\text { use needs prescription from provider; } \\
\text { not recommended for those with } \\
\text { contraindications to estrogen use; may } \\
\text { cause breast tenderness, spotting, or } \\
\text { nausea in the beginning; women need } \\
\text { to be comfortable placing it }\end{array}$ \\
\hline Patch & $>99$ & 91 & 49 & $\begin{array}{l}\text { Easy to use (weekly method); does } \\
\text { not interrupt sex; may make periods } \\
\text { lighter/shorter and regular; may clear } \\
\text { up acne; may reduce menstrual cramps }\end{array}$ & $\begin{array}{l}\text { Need to change it every month; its } \\
\text { use needs prescription from provider; } \\
\text { not recommended for those with } \\
\text { contraindications to estrogen use; may } \\
\text { cause breast tenderness, spotting, or } \\
\text { nausea in the beginning }\end{array}$ \\
\hline $\begin{array}{l}\text { Oral } \\
\text { contraceptive } \\
\text { pills }\end{array}$ & $>99$ & 91 & 55 & $\begin{array}{l}\text { Easy to use; does not interrupt sex; } \\
\text { may make periods lighter; may clear up } \\
\text { acne; may reduce menstrual cramps }\end{array}$ & $\begin{array}{l}\text { Need to take it every day; need } \\
\text { prescription from provider; not } \\
\text { recommended for those with } \\
\text { contraindications to estrogen use; may } \\
\text { cause breast tenderness, spotting, or } \\
\text { nausea in the beginning }\end{array}$ \\
\hline \multicolumn{6}{|c|}{ Other methods } \\
\hline Male condom & 98 & 82 & $\mathrm{~N} / \mathrm{A}$ & $\begin{array}{l}\text { Protects against STIs; no prescription } \\
\text { required; available in latex and nonlatex } \\
\text { forms and with or without spermicide }\end{array}$ & $\begin{array}{l}\text { Must be used every time; may reduce } \\
\text { sensitivity }\end{array}$ \\
\hline $\begin{array}{l}\text { Female } \\
\text { condom }\end{array}$ & 95 & 79 & $\mathrm{~N} / \mathrm{A}$ & $\begin{array}{l}\text { Protects against STIs; no prescription } \\
\text { required; can be used even if allergic } \\
\text { to latex }\end{array}$ & $\begin{array}{l}\text { Must be used every time; must feel } \\
\text { comfortable placing it into vagina }\end{array}$ \\
\hline Diaphragm & 94 & 88 & $\mathrm{~N} / \mathrm{A}$ & $\begin{array}{l}\text { Can be placed hours before sex; does } \\
\text { not have any hormones; can be used } \\
\text { while breastfeeding }\end{array}$ & $\begin{array}{l}\text { Some diaphragms need fitting; needs } \\
\text { to be used every time; may cause } \\
\text { vaginal irritation; needs to be used with } \\
\text { spermicide }\end{array}$ \\
\hline
\end{tabular}


Table I (Continued)

\begin{tabular}{|c|c|c|c|c|c|}
\hline Method & $\begin{array}{l}\text { Perfect } \\
\text { use efficacy } \\
(\%)^{* *}\end{array}$ & $\begin{array}{l}\text { Typical } \\
\text { use efficacy } \\
(\%)^{* * *}\end{array}$ & $\begin{array}{l}\text { I-year } \\
\text { continuation } \\
\text { rate }(\%)\end{array}$ & Benefits & Disadvantages \\
\hline Cervical cap & $\mathrm{N} / \mathrm{A}$ & $7 I-86$ & N/A & $\begin{array}{l}\text { Can be placed hours before sex; does } \\
\text { not have any hormones; can be used } \\
\text { while breastfeeding; does not require } \\
\text { prescription }\end{array}$ & $\begin{array}{l}\text { Must be used every time; some women } \\
\text { may have a hard time placing it into } \\
\text { the vagina; may cause vaginal irritation; } \\
\text { needs to be used with spermicide }\end{array}$ \\
\hline Sponge & $80-91$ & $76-82$ & $\mathrm{~N} / \mathrm{A}$ & $\begin{array}{l}\text { Can be placed hours before sex; } \\
\text { does not have hormones; does not } \\
\text { require prescription; can be used while } \\
\text { breastfeeding }\end{array}$ & $\begin{array}{l}\text { Must be used every time; some women } \\
\text { may have a hard time placing it into } \\
\text { the vagina; may cause vaginal irritation; } \\
\text { needs to be used with spermicide }\end{array}$ \\
\hline Withdrawal & 96 & 78 & $N / A$ & No prescription necessary; no costs & $\begin{array}{l}\text { Difficult to perform perfectly every } \\
\text { time; relies on male knowing when he } \\
\text { will ejaculate }\end{array}$ \\
\hline $\begin{array}{l}\text { Fertility } \\
\text { awareness } \\
\text { methods }\end{array}$ & $95-99$ & $76-88$ & N/A & $\begin{array}{l}\text { No prescription necessary; does not } \\
\text { contain hormones; no side effects; } \\
\text { helps women to learn about their } \\
\text { body }\end{array}$ & $\begin{array}{l}\text { Requires a lot of effort, record-keeping, } \\
\text { and self-control; requires abstinence; } \\
\text { some methods do not work for women } \\
\text { with irregular periods }\end{array}$ \\
\hline Spermicide & 82 & 72 & $N / A$ & $\begin{array}{l}\text { Easy to use; no prescription necessary } \\
\text { (available over the counter); does not } \\
\text { affect hormones; can be used while } \\
\text { breastfeeding }\end{array}$ & $\begin{array}{l}\text { May cause allergic reactions; needs to } \\
\text { be used every time; may be messy }\end{array}$ \\
\hline
\end{tabular}

Notes: Data from Centers for Disease Control and Prevention, ${ }^{44}$ and Hatcher et al. ${ }^{45} * *$ Pregnancy rates during perfect use show how effective methods can be, where perfect use is defined as following the directions for use. ****Pregnancy rates during typical use show how effective the different methods are during actual use (including inconsistent or incorrect use).

Abbreviations: CDC, Centers for Disease Control and Prevention; IUDs, intrauterine devices; N/A, not applicable; STls, sexually transmitted infections.

In the study by Langston et al, ${ }^{23}$ a randomized controlled trial (RCT) using a version of the WHO Decision-Making Tool (DMT) for Family Planning Clients and Providers was conducted among women presenting for a spontaneous or induced abortion. Women were randomized to receive usual care or usual care and structured counseling. This study evaluated the effects of structured counseling on women choosing very effective contraceptive methods at the time of their abortion, method initiation, and method continuation for 3 months.

Structured counseling consisted of a trained research coordinator who read and displayed the DMT that was previously found to be effective in improving communication

Table 2 Categories of medical eligibility criteria

\begin{tabular}{ll}
\hline Category & Description \\
\hline I & $\begin{array}{l}\text { A condition for which there is no restriction for the use } \\
\text { of the contraceptive method }\end{array}$ \\
& $\begin{array}{l}\text { A condition for which the advantages of using the method } \\
\text { generally outweigh the theoretical or proven risks }\end{array}$ \\
& $\begin{array}{l}\text { A condition for which the theoretical or proven risks } \\
\text { usually outweigh the advantages of using the method }\end{array}$ \\
& $\begin{array}{l}\text { A condition that represents an unacceptable health risk if } \\
\text { the contraceptive method is used }\end{array}$
\end{tabular}

Note: Adapted from US Medical Eligibility Criteria for Contraceptive Use, 2010 by Centers for Disease Control and Prevention (CDC). ${ }^{44}$ among patients choosing a new contraceptive method. ${ }^{24}$ The DMT is a double-sided visual aid that presents the available contraceptives, provides information regarding medical eligibility criteria and possible side effects of each method, and advises on when to seek medical care. Each contraceptive method was made available during the encounters for patients to feel and visualize each possibility. Usual care consisted of contraceptive counseling at the discretion of the physician at the time of patient's suction aspiration procedure. Interpretation of results from this study indicated that structured counseling had little impact on the choice of contraceptive, initiation, or continuation. However, it is worth mentioning that Langston et $\mathrm{a}^{23}$ had several limitations to their intervention, and therefore, the effects of structured counseling should not be ruled out.

Another study compared different health education resources for their ability to communicate contraceptive information. ${ }^{25,26}$ Participants were randomized to receive educational material either through pamphlets or an audiovisual program with a familiar or unfamiliar narrator or an oral presentation by a physician or a combination of all the three resources. It was reported that participants gained less knowledge from oral presentations by a physician provider compared to that of an audiovisual presentation by an unfamiliar narrator. ${ }^{25,26}$ Participant satisfaction was greatest 
among those who received a combination of resources compared to those receiving pamphlets only. ${ }^{26}$

A study by Omu et al among high-parity pregnancy women in Nigeria focused on sterilization acceptance while providing information on all known methods of contraception. ${ }^{25,27}$ This intervention consisted of multisession encounters throughout a participant's pregnancy, emphasizing on contraceptive methods and the health effects linked to multiple pregnancies. Only those staff members who had undergone specific training through Family Health International were eligible to provide counseling. The control group received standard family planning information provided by untrained staff. The results of this study indicate that $71 \%$ of women in the intervention group were using an effective method of birth control 6 weeks postpartum, compared to $51 \%$ of those in the control group. ${ }^{27}$

A study by Stephenson et al analyzed data from the Family Planning in Couples with human immunodeficiency virus (HIV), which aimed to reduce fertility among concordant HIV-positive and HIV-discordant couples in Zambia using video presentations. ${ }^{25,28}$ Participants underwent a video-based informed consent that included the detailed contraceptive methods available. Couples were then randomized to view videos on contraceptive methods, future family planning behaviors, or both with a counselor available to answer questions. Participants in the control group viewed educational videos unrelated to contraceptives, but still had access to family planning services. This study showed a dramatic decline in the percentage of couples using no contraceptives or condoms in all study arms. The most popular methods chosen for new adopters were oral contraceptive pill, and injectable for all study arms. Couples viewing the methods' video were more likely to choose the intrauterine device. ${ }^{28}$

In the study by Kraft et $\mathrm{al}^{29}$ also, group-based intervention was provided over multisessions for couples in the Los Angeles and Oklahoma City areas. ${ }^{25}$ Couples were randomized to a three-session intervention, each lasting 2.5 hours over the course of 3 weeks, or to a one-session intervention lasting 1.5-2 hours. Both groups received a comprehensive session on contraceptive methods, their correct use, and their efficacy for preventing pregnancy and disease. ${ }^{29}$ The intervention group also received sessions focusing on increasing communication between couples and perceived risk of unintended pregnancies and sexually transmitted diseases. ${ }^{29}$ There was no statistically significant difference in consistent contraceptive use between the study groups at 6-month follow-up; however, increased use of contraceptives over time was seen in both groups. ${ }^{25,29}$
In the study by Steiner et al, women recruited from various US states were randomized to review three different tables on contraceptive effectiveness information..$^{25,30}$ The first table demonstrating rates of pregnancy based on the contraceptive method was created by the Food and Drug Administration. The second table demonstrating rates of pregnancy by the effectiveness of the contraceptive method was created by the WHO. The third table was created by Steiner et $\mathrm{a}^{30}$ and lists the contraceptive methods by categories of effectiveness, with limited information on sexually transmitted disease protection. In this study, the participants preferred understanding relative effectiveness of contraceptives through the table that compared different birth control methods. However, participants exposed to categorical data did overestimate the risk of pregnancy. The authors suggest that a combined table of categorical effectiveness with a general range of risk by the contraceptive method would provide an accurate understanding of the relative and absolute risks of pregnancy. ${ }^{30}$

In another similar study by Steiner et $a{ }^{31},{ }^{31}$ the authors compared three different approaches for increasing the understanding of contraceptive effectiveness ${ }^{25}$ among Indian and Jamaican women. Following the results of Steiner et al's earlier study, tables were created that presented contraceptive methods based on effectiveness categories. ${ }^{25,31}$ The first table presented the effectiveness stratified by the degree of contraceptive use (consistency versus correct use). The second table grouped contraceptive methods over four categories of effectiveness. The third table presented the contraceptive methods on a continuum from least to most effective. The results of this study show that no chart improved a participant's knowledge of contraceptive effectiveness over the other; however, ranking the contraceptive methods on a continuum was easier to understand. ${ }^{31}$

\section{New technology and contraception counseling}

Interactive, multimedia, computer-based programs provide a novel platform for delivering health information. ${ }^{32} \mathrm{~A}$ study by Kofinas et $\mathrm{al}^{33}$ looked at the effects of social media on improving patient knowledge and preference for contraceptives. Participants of this study were randomized to receive either standard counseling and pamphlet education or standard counseling and Facebook education. The pamphlets were acquired from the American College of Obstetricians and Gynecologists. The Facebook page was then created based on the same content within these pamphlets. For the purposes of this study, participants were allowed 30 minutes of Facebook time within the confines of an office setting. 
A validated contraceptive knowledge survey (Contraceptive Knowledge Inventory) was used at pre- and postintervention for both study arms. The results of this RCT indicate that Facebook users performed better on postintervention surveys compared to the pamphlet group. Participant satisfaction with counseling sessions was significantly higher in the Facebook group. In addition, the Facebook group also had a higher preference for LARCs compared to the pamphlet group. ${ }^{33}$

Garbers et $\mathrm{al}^{1}$ developed a personalized contraceptive counseling intervention. The intervention involved utilizing a computer module that was adapted from a contraceptive algorithm and made appropriate for women of all literacy levels. Women were randomized to receive intervention with either tailored reading material or generic reading material. The contraceptive counseling module consisted of 50 questions covering contraceptive history, preferences, priorities, and medical and sexual health. Those who were allocated to receive generic reading material only answered ten sociodemographic questions using a touchscreen interface, similar to the intervention groups. Results of this study indicate that the participants who utilized the contraceptive module were more likely to choose an effective form of contraception. Also, module users who received tailored reading material were more likely to adhere to their method of choice and have continued its use at 4 months follow-up.

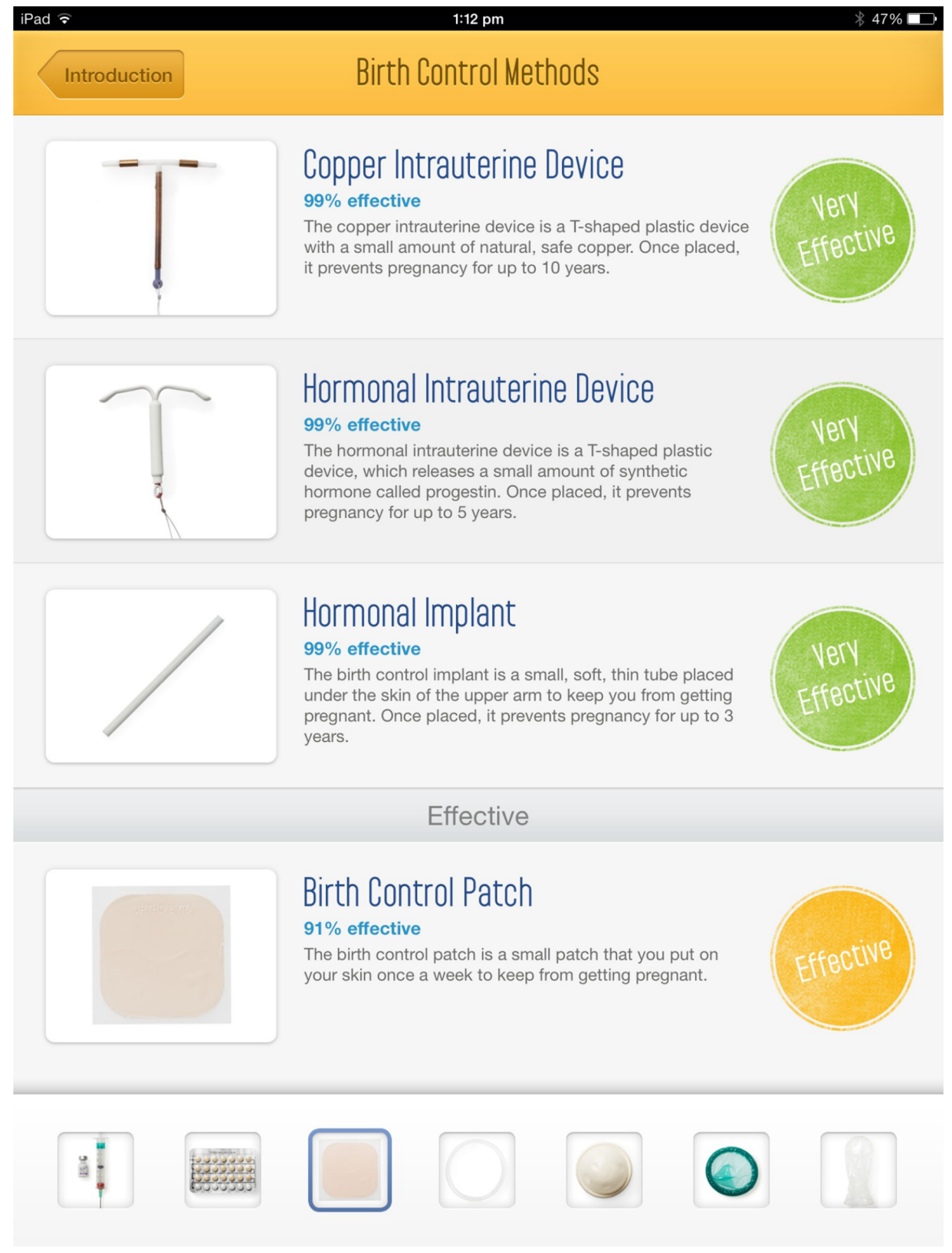

Figure I Mobile application "Plan A Birth Control". ${ }^{43}$ 
Gilliam et $\mathrm{al}^{34}$ identified the barriers to LARC services among women in three Chicago Title X family planning clinics. This assessment revealed that the nonuse of waiting room downtime was a missed opportunity for patient interaction. Participants of the Gilliam et $\mathrm{al}^{34}$ study were randomized such that the comparison group was offered tablets with the developed application during their clinic waiting times plus standard care (contraceptive counseling and visit by a nurse practitioner to receive the chosen method of birth control). An analysis of baseline and postintervention surveys revealed that the application was successful at improving the knowledge of contraceptive effectiveness. The application was rated highly with greater than $90 \%$ of participants stating that it was easy to use, provided useful information that was not previously known to them, and was good use of their time.

At the University of California Los Angeles, a mobile application called Plan A Birth Control (Figure 1) was developed and tested among women to understand its influence on contraceptive choice and knowledge. ${ }^{35}$ The mobile application has information about ten different forms of reversible contraceptive methods (Figure 1), which range from very effective to least effective methods. The application includes questions to screen patients for medical eligibility of birth control methods with a built-in warning for suspected medical contraindications to usage of the method chosen. Patients are advised to inform their health care provider about any medical conditions in question prior to choosing a birth control method. One hundred and twenty participants were recruited for an RCT. Participants were assigned by simple randomization to contraception counseling via tablet or health educator. We compared participants' contraceptive choice and knowledge of the chosen contraceptive method between the two groups. Contraceptive method choice and knowledge of long-acting reversible methods did not differ between the groups. ${ }^{35}$

\section{Conclusion}

Patients desire active involvement of their family planning provider during the process of choosing a contraceptive method. They value intimacy and provision of adequate information during the contraceptive counseling encounter. ${ }^{36}$ Multiple modalities have been presented in this review to highlight the best approach to inform patients of their contraceptive options. Health care providers must consider the most effective contraceptive methods that best fit patients' reproductive life plan and personal needs. These factors should not be disregarded for they influence an individual's compliance, continued use, and efficacy of the contraceptive method itself. ${ }^{1,37-39}$ Counseling sessions should consist of visual aids that list the contraceptives by their effectiveness, as they are perceived to be efficient and generally preferred by patients. Providers should address family planning over multiple time points to ensure patients' satisfaction with the choice of method and encourage their adherence. Beyond a patient-physician encounter, opportunities to enhance a patient's clinical experience through group sessions by trained health educators or the added value of social media and computer applications should be considered. Providers should familiarize themselves with USMEC and US SPR to prescribe methods that are ensured to be safe despite preexisting medical conditions. Furthermore, the adaptations highlighted in this article would reinforce personalized contraceptive counseling to enable patient-targeted messaging about the effectiveness of contraceptives ${ }^{40}$ and for improving the access $^{41,42}$ to all available contraceptives. We strongly believe that such personalized contraception counseling is the key for effective contraceptive usage and reduction of unintended pregnancies.

\section{Disclosure}

The authors report no conflicts of interest in this work.

\section{References}

1. Garbers S, Meserve A, Kottke M, Hatcher R, Chiasson MA. Tailored health messaging improves contraceptive continuation and adherence: results from a randomized controlled trial. Contraception. 2012;86(5):536-542.

2. Gipson JD, Koenig MA, Hindin MJ. The effects of unintended pregnancy on infant, child, and parental health: a review of the literature. Stud Fam Plann. 2008;39:18-38.

3. Logan C, Holcombe E, Manlove J, Ryan S. The Consequences of Unintended Childbearing: A White Paper. Washington: Child Trends; 2007.

4. Pulle L, Klerman LV, Tang H, Baker BA. The extent of pregnancy mistiming and its association with maternal characteristics and behaviors and pregnancy outcomes. Perspect Sex Reprod Health. 2002;34:206-211.

5. Cheng D, Schwarz EB, Douglas E, Horon I. Unintended pregnancy and associated maternal preconception, prenatal and postpartum behaviors. Contraception. 2009;79(3):194-198.

6. Finer LB, Zolna MR. Shifts in intended and unintended pregnancies in the United States, 2001-2008. Am J Pub Health. 2014;104.S1: S43-S48.

7. Burnhill MS. Contraceptive use: the US perspective. Int J Gynecol Obstet. 1998;62:S17-S23.

8. Frost JJ, Darroch, JE, Remez L. Improving contraceptive use in the United States. Issues Brief (Alan Guttmacher Inst). 2008:1-8.

9. Mosher WD, Jones J. Use of contraception in the United States: 1982-2008. Vital Health Stat. 2010;23:1-44.

10. Kost K, Singh S, Vaughan B, Bankole A. Estimates of contraceptive failure from the 2002 National Survey of Family Growth. Contraception. 2008;77:10-21.

11. Institute of Medicine (US) Committee on Quality of Health Care in America, editors. Crossing The Quality Chasm: a New Health System for the 21st Century. Washington, DC: National Academies Press; 2001.

12. Street RL Jr, Makoul G, Arora NK, Epstein RM. How does communication heal? Pathways linking clinician-patient communication to health outcomes. Patient Educ Couns. 2009;74:295-301. 
13. Stewart MA. Effective physician-patient communication and health outcomes: a review. CMAJ. 1995;152:1423-1433.

14. Brown W, Ottney A, Nguyen S. Breaking the barrier: the Health Belief Model and patient perceptions regarding contraception. Contraception. 2011;83(5):453-458.

15. Frost JJ, Singh S, Finer LB. Factors associated with contraceptive use and nonuse, United States, 2004. Perspect Sex Reprod Health. 2007;39(2):90-99.

16. Farrokh-Eslamlou H, Aghlmand S, Khorasan-Zavaren D, et al. Structured versus routine family planning counselling for contraception. Cochrane Database Syst Rev. 2014;7: CD011211.

17. Speidel JJ, Harper CC, Shields WC. The potential of long-acting reversible contraception to decrease unintended pregnancy. Contraception. 2008;78(3):197-200.

18. Moos MK, Bartholomew NE, Lohr KN. Counseling in the clinical setting to prevent unintended pregnancy: an evidence-based research agenda. Contraception. 2003;67(2):115-132.

19. French RS, Wellings K, Cowan FM. How can we help people to choose a method of contraception? The case for contraceptive decision aids. J Fam Plann Reprod Health Care. 2009;35(4):219-220.

20. US Medical Eligibility Criteria for Contraceptive Use, 2010: adapted from the World Health Organization Medical Eligibility Criteria for Contraceptive Use, 4th Edition. MMWR Recomm Rep. 2010;59:1.

21. Centers for Disease Control and Prevention. US Selected Practice Recommendations for Contraceptive Use, 2013: adapted from the World Health Organization Selected Practice Recommendations for Contraceptive Use, 2nd Edition. MMWR Recomm Rep. 2013;62:1.

22. Dehlendorf C, Colleen K, Borrero S. Contraceptive counseling: best practices to ensure quality communication and enable effective contraceptive use. Clin Obstet Gynecol. 2014;57(4):659-673.

23. Langston AM, Rosario L, Westhoff CL. Structured contraceptive counseling - a randomized controlled trial. Patient Educ Couns. 2010;81(3):362-367.

24. Kim YM, Davila C, Tellez C, Kols A. Evaluation of the World Health Organization's family planning decision-making tool: improving health communication in Nicaragua. Patient Educ Couns. 2007;66:235-242.

25. Lopez LM, Steiner MJ, Grimes DA, Schulz KF. Strategies for communicating contraceptive effectiveness. Cochrane Database Syst Rev. 2008;2:CD006964.

26. Marshall WR, Rothenberger LA, Bunnell SL. The efficacy of personalized audiovisual patient-education materials. J Fam Pract. 1984; 19(5):659-663.

27. Omu AE, Weir SS, Janowitz B, Covington DL, Lamptey PR, Burton NN. The effect of counseling on sterilization acceptance by high-parity women in Nigeria. Int Fam Plan Perspect. 1989;15(2): 66-71.

28. Stephenson R, Vwalika B, Greenberg L, et al. A randomized controlled trial to promote long-term contraceptive use among HIV-serodiscordant and concordant positive couples in Zambia. JWomen's Health(Larchmt). 2011;20(4):567-574.

29. Kraft JM, Harvey SM, Thorburn S, Henderson JT, Posner SF, Galavotti C. Intervening with couples: assessing contraceptive outcomes in a randomized pregnancy and HIV/STD risk reduction intervention trial. Womens Health Issues. 2007;17(1):52-60.
30. Steiner MJ, Dalebout S, Condon S, Dominik R, Trussell J. Understanding risk: a randomized controlled trial of communicating contraceptive effectiveness. Obstet Gynecol. 2003;102(4):709-717.

31. Steiner MJ, Trussell J, Mehta N, Condon S, Subramaniam S, Bourne D. Communicating contraceptive effectiveness: a randomized control trial to inform a World Health Organization family planning handbook. Am J Obstet Gynecol. 2006;195(1):85-91.

32. Guse K, Levine D, Martins S, et al. Interventions using new digital media to improve adolescent sexual health: a systematic review. $J$ Adolesc Health. 2012;51:535-543.

33. Kofinas JD, Varrey A, Sapra KJ, Kanj RV, Chervenak FA, Asfaw T. Adjunctive social media for more effective contraceptive counseling: a randomized controlled trial. Obstet Gynecol. 2014;123(4):763-770.

34. Gilliam ML, Martins SL, Bartlett E, Mistretta SQ, Holl JL. Development and testing of an iOS waiting room "app" for contraceptive counseling in a Title X family planning clinic. Am J Obstet Gynecol. 2014;211(5):481.

35. Sridhar A, Chen A, Forbes ER, Glik D. Mobile application for information on reversible contraception: a randomized controlled trial. Am J Obstet Gynecol. 2015;212(6):774.e1-e7. doi:10.1016/j.ajog.2015.01.011. Epub 2015 Jan 9.

36. Dehlendorf C, Levy K, Kelley A, Grumbach K, Steinauer J. Women's preferences for contraceptive counseling and decision making. Contraception. 2013;88(2):250-256. doi: 10.1016/j.contraception.2012.10.012. Epub 2012 Nov 21.

37. Steiner M, Dominik R, Trussell J, Hertz-Picciott I. Measuring contraceptive effectiveness: a conceptual framework. Obstet Gynecol. 1996;88:24S-30S.

38. Steiner MJ. Contraceptive effectiveness: what should the counseling message be? JAMA. 1999;282:1405-1407.

39. Grimes DA. Forgettable contraception. Contraception. 2009;80: 497-499.

40. Rosenberg MJ, Waugh MS, Long S. Unintended pregnancies and use, misuse and discontinuation of oral contraceptives. J Reprod Med. 1995;40:355-360

41. Westhoff CL, Heartwell S, Edwards S, et al. Oral contraceptive discontinuation: do side effects matter? Am J Obstet Gynecol. 2007;196:412e1-e6.

42. Huber LR, Hogue CJ, Stein AD, et al. Contraceptive use and discontinuation: findings from the contraceptive history, initiation, and choice study. Am J Obstet Gynecol. 2006;194:1290-1295.

43. Dr Aparna Sridhar, UCLA 2013. Plan A Birth Control. [Mobile app]. Accessed March 3, 2016.

44. Centers for Disease Control and Prevention. US selected practice recommendations for contraceptive use, 2013. MMWR Recomm Rep. 2013;62(RR-05):1-60.

45. Hatcher RA, Trussell J, Nelson AL, Cates W Jr, Kowal D, Policar M. Contraceptive Technology. New York, Ardent Media, 2011.
Open Access Journal of Contraception

\section{Publish your work in this journal}

Open Access Journal of Contraception is an international, peerreviewed, open access, online journal, publishing original research, reports, reviews and commentaries on all areas of contraception. In addition to clinical research, demographics and health-related aspects, the journal welcomes new findings in animal and preclinical studies
Dovepress

relating to understanding the biological mechanisms and practical development of new contraceptive agents. The manuscript management system is completely online and includes a very quick and fair peer-review system. Visit http://www.dovepress.com/testimonials.php to read real quotes from published authors. 